\title{
Companies ponder how truly 'personal' medicines can get
}

Cancer drugs such as Herceptin are known as 'personalized medicines' because they are prescribed for subgroups of patients who share specific genetic traits. But truly individualized therapies are represented by treatments such as Provenge, which consists of patients' own cells that have been extracted, exposed to an antigen that trains them to go after prostate cancer and re-infused.

The latter category is a tougher nut to crack, yet, ever since the US Food and Drug Administration (FDA) approved Provenge a year ago, cell-based personalized medicine has continued to garner interest. A course of three infusions of the treatment costs $\$ 93,000$, but demand is still high. Earlier this year, Dendreon, the Seattle-based company that makes Provenge, announced it had received FDA approval to expand the number of production facilities for the product from 12 to 48 .

Optimists are quick to cite Provenge as the crest of a wave of new therapies. "It has huge implications," says Ronald Levy, a co-founder of Idec Pharmaceuticals (which merged to form Biogen Idec in 2003). "There may be 50 other therapies who hope to follow in the Provenge example."

Although Levy, who is now at the Stanford University School of Medicine in California, is buoyant about the future of personalized cellbased therapies, he learned the hard way that some forms of personalized medicine prove too cumbersome to scale up. In the 1980s, he began creating antibodies designed for individual patients with lymphoma. Levy and his colleagues would identify telltale receptors on the wayward lymphocytes for each patient and then produce personalized antibodies designed to attack only his or her cancerous cells. Some 50 patients were treated with antibodies made this way, says Levy. "It worked most of the time, but it became economically unfeasible." So he and his Idec colleagues instead developed the blockbuster rituximab, an antibody that targets a protein found on all B cells, allowing many patients with lymphoma to receive the same drug.

Bill Rastetter, a former chief executive at Idec and now a partner at Venrock, a venture-capital firm in Palo Alto, California, says efficacy as well as economics led him to decide against making individualized antibodies. Idec's projected selling price for the personalized antibody approach was $\$ 50,000$ per course of therapy, with about one in five patients showing remissions longer than those projected from chemotherapy alone. In contrast, about six out of ten patients benefitted from rituximab, he says, at a cost of

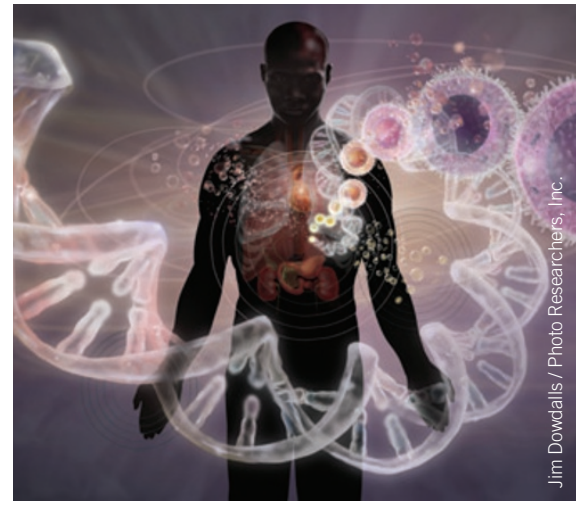

Take it personally: Tailored drugs cost more.

about $\$ 10,000$ per treatment course. (Levy notes that the approaches were never tested side by side, so efficacy is hard to compare.)

Medicines produced for specific individuals may still be useful for diseases beyond cancer. Teams at Stanford University, the University of Minnesota-Twin Cities and elsewhere hope to develop treatments for the skin disease epidermolysis bullosa, which can be life threatening in severe cases. The plan is to collect cells from patients, convert them to induced pluripotent stem cells, correct mutations with an array of specially designed DNA-cutting enzymes and then grow these cells into personal skin grafts for transplantation (Nat. Med. 17, 405-407, 2011).

For now, the project is too risky for companies to invest in, says Anthony Oro of the Stanford University School of Medicine, part of a research team that received $\$ 12$ million from the California Institute of Regenerative Medicine (CIRM) to work on the research. "That's the bet that CIRM is taking," says Oro, "that we can take some of the risk out."

\section{Cell-based sway}

"There has been a small but gradual increase in the last five to ten years in patient-specific cell therapies entering the clinic," says Keith Wonnacott, chief of the cell therapy branch at the FDA.

One reason for the increased interest in personalized cell-based therapies is that such treatments have improved drastically in their effectiveness, says Carl June, a clinician at the University of Pennsylvania School of Medicine in Philadelphia. Another reason is that drug companies' pipelines of products in development are relatively empty, making unconventional products more attractive.

When it comes to truly personalized medicines, autologous cell transplant therapies such as Provenge seem to have the edge. In March of last year, Third Rock Ventures and other investors poured $\$ 35$ million into Genetix Pharmaceuticals (recently renamed Bluebird Bio), which is genetically altering cells from patients with blood disorders such as sickle cell anemia, and re-infusing the modified cells. And in October of last year, GlaxoSmithKline made a $€ 10$ million ( $\$ 14.5$ million) payment to the San Raffaele Telethon Institute for Gene Therapy in Milan to codevelop treatments for severe combined immune deficiency and other rare genetic disorders using a similar approach.

June believes some patient-specific medicines now in development could be both more effective and cheaper than current treatments, particularly if they require only a single dose of cells. He is running a clinical trial in which $\mathrm{T}$ cells are collected from patients with leukemia, genetically modified to respond to cancer cells and then re-introduced to patients, as well as trials in which $\mathrm{T}$ cells from patients with HIV are genetically modified to resist infection. Not including the cost of genetic modification, collecting, modifying and delivering these cells costs around $\$ 15,000$ per patient, he says, far less than bone marrow transplants, which cost about $\$ 250,000$.

But it could be a hard sell. Malcolm Brenner, a clinician at Baylor College of Medicine in Houston, who is running clinical trials in which patients' immune cells are modified to better recognize cancer, estimates that administering patients' own cells back to them is roughly four times more expensive than employing products that use cells from a common source, and if production is scaled up beyond small clinical trials the costs of the latter can become even cheaper.

And drug approval does not guarantee a market success. "We still don't know how successful Dendreon will be in commercializing the drug," says Eric Schmidt, a research analyst at Cowen and Company in New York. Most drug companies are set up to sell products that can be made in bulk and stored, but patientspecific medicines require collecting and processing samples individually. Not only is this more expensive, but also mix-ups between samples or in collection and delivery could be disastrous.

It has been a long, hard road since the start of efforts to make medicines from patients' own cells, says Brenner, and personalized therapies are still very much a work in progress. "It's twenty years on," Brenner says, "and we still only have Provenge."

Monya Baker 